\title{
Ultrastructure and Immunocytochemistry of the Islet Organ of Osteoglossomorpha (Teleostei)
}

\author{
Azza A. Al-Mahrouki and John H. Youson ${ }^{1}$ \\ D epartment of Zoology and Division of Life Sciences, U niversity of Toronto at Scarborough, \\ Scarborough, Ontario M 1C 1A4, Canada
}

Accepted September 7, 1999

Both routine electron microscopy and immunocytochemistry with protein A-gold were used to identify the cell types within the islet organs of four species of teleosts (Osteoglossum bicirrhosum, Pantodon buchholzi, Notopterus chitala, and $\mathrm{G}$ nathonemus petersii) within Osteoglossomorpha, a subdivision with an ancient lineage. Four primary endocrine cell types, A, B, D, and F, were identified within the islets of the four species examined. The B- and D-cells were located mainly in the central core of the islet in the four species. In general, the A-cells were located at the islet periphery in all of the four species but in P. buchholzi and N. chitala they were also differently distributed toward the islet core. F-cells were present only at the islet periphery. Granules of B-cells in three species had a relatively homogeneous shape of the matrix core, but in 0 . bicirrhosum, the shape varied greatly. Variation in matrix shape of B-cell granules may indicate a different conformation of insulin molecules among at least some species of osteoglossomorphs, and this observation may have some taxonomic significance. Two somatostatin-containing (SST) D-cell types (D1 and DX) with granules of different shape were observed in all four species of osteoglossomorphs. The granules of the two D-cells immunostained either with anti-SST-25 and anti-SST-14 (D1-cells) or with anti-SST-34 (DX-cells). Immunocytochemistry confirmed that A-cells, containing glucagon-family peptides, and F-cells, containing peptides of the pancreatic polypeptide family, had gran-

${ }^{1}$ To whom reprint requests should be addressed. Fax: (416) 287-7676. E-mail: youson@scar.utoronto.ca. ules of different shape. The cells of the islet organs of these osteoglossomorphs are more similar to those in more derived teleosts than they are to those of nonteleost actinopterygians. 1999 Academic Press

Key Words: G nathonemus petersii, islet organ; immunocytochemistry; Notopterus chitala; osteoglossomorphs; Osteoglossum bicirrhosum; Pantodon buccholzi; ultrastructure.

The ancient origin of members of the subdivision (superorder) Osteoglossomorpha among the teleosts (Patterson and Rosen, 1977), their pivotal position in teleost evolution, and the unsettled debate over their taxonomy make osteoglossomorphs an interesting case for investigating the phylogenetic development of organ systems. Included among these systems is the endocrine pancreas (islet organ) and its peptides.

Until recently, only passing attention had been made to the pancreas of members of the order Osteoglossiformes (McCormick, 1925; Epple and Brinn, 1975; Langer et al., 1979). However, a detailed immunohistochemical study of the gastro-entero-pancreatic (GEP) system (Al-Mahrouki and Youson, 1998) reported that various species of osteoglossomorphs showed structural diversity which reflected their distinctive taxonomic groupings. This study also suggested that further analysis of the endocrine cell types of the islet tissue and their immunoreactivity might provide additional data useful for taxonomic comparisons.

The different cell types in the islet organs of teleosts 
have been identified in several immunocytochemical and ultrastructural studies (Lozano and Agulleiro, 1986; Beccaria et al., 1990; Agulleiro et al., 1993; GomezVisus et al., 1996); recently, this type of investigation was extended to include the gar (Groff and Youson, 1998), a nonteleost actinopterygian (ray-finned fish) of ancient lineage (Gardiner et al., 1996).

This study aims to provide further identification of the cell types within the islet organ of the Osteoglossomorpha to extend our knowledge of the structural diversity or conformity of this organ among actinopterygian fishes in general and among the taxonomic groups of osteoglossomorphs in particular.

\section{MATERIALS AND METHODS}

\section{Animals}

Adult specimens of Osteoglossum bicirrhosum (silver arawana), Pantodon buchholzi (butterfly fish), Notopterus chitala (feather fin knife fish), and Gnathonemus petersii (elephant fish) were obtained from several commercial fish aquaria within the Toronto area. A total of 21 animals (minimum of 3 for each species) were sacrificed by an overdose of $0.05 \%$ tricaine methanesulfonate (MS-222) in their holding water.

\section{Tissue Preparation}

Routine electron microscopy. The regions of the pancreas containing the islet organ (Al-Mahrouki and Youson, 1998) were excised from the viscera, diced, and fixed in a mixture of $0.1 \%$ glutaraldehyde and $4 \%$ paraformaldehyde in $0.1 \mathrm{M}$ phosphate buffer, $\mathrm{pH} 7.4$ (Millonig, 1961), overnight at $4^{\circ} \mathrm{C}$. After this primary fixation, the tissues were washed in buffer and subsequently postfixed in 1\% phosphate-buffered osmium tetroxide $\left(\mathrm{OsO}_{4}\right)$ for $1 \mathrm{~h}$ at room temperature. The tissues were then washed in buffer, dehydrated in a graded series of ethanols, and embedded in Spurr's low-viscosity embedding medium (Poly-sciences, Inc., Warrington, PA). Thick sections $(0.5 \mu \mathrm{m})$ were mounted on glass slides, stained with $1 \%$ toluidine blue in saturated tetraborate, and used to locate islet tissue using light microscopy. Ultrathin sections were cut with glass knives, mounted on uncoated copper grids, and stained with uranyl acetate and lead citrate. Sections were examined in a Siemens Elmiskop-102 electron microscope.

Immunocytochemistry. Tissues were primary fixed as described above for $2 \mathrm{~h}$. Unosmicated tissues were dehydrated and embedded in Spurr's low-viscosity embedding medium. Ultrathin sections were mounted on nickel grids. The nonspecific binding sites were blocked by incubating the grids on CAS-block (Zymed Laboratories, Inc., San Francisco, CA) for $10 \mathrm{~min}$. The tissues were then incubated for $2 \mathrm{~h}$ at room temperature in one of the following antisera: (1) guinea pig anti-bovine insulin (anti-mINS; a kind gift of Dr. C. Yip, University of Toronto), diluted 1:750; (2) rabbit anti-lamprey somatostatin-34, diluted 1:500 (anti-SST34); (3) rabbit anti-salmon somatostatin-25 (anti-SST25), diluted 1:500; (4) rabbit anti-somatostatin-14 IgG fraction (anti-SST-14; LINCO Research, Inc., St. Charles, $\mathrm{MO}$ ), diluted 1:1000; (5) rabbit anti-salmon polypeptide tyrosine tyrosine (anti-PYY), diluted 1:500; and (6) rabbit anti-porcine glucagon (anti-GLU; Zymed Laboratories, Inc.), diluted 1:500. Anti-SST-25, anti-SST-34, and anti-PYY were kind gifts of Dr. E. M. Plisetskaya, University of Washington). The incubation in the primary antiserum was followed by several washes in phosphate-buffered saline (PBS) for $20 \mathrm{~min}$ and incubation for $10 \mathrm{~min}$ in CAS-block solution. Grids were then blotted gently and transferred to $10 \mathrm{~nm}$ protein A-gold (Sigma Chemical Co., St. Louis, MO; diluted 1:20 with the blocking solution) for $1 \mathrm{~h}$ at room temperature. Several washes in PBS followed, with a final wash in distilled water. The tissue was then contrasted with uranyl acetate and lead citrate. For double-immunogold labeling, the same procedures as above were followed, except that the grids were dried before the final distilled-water wash and the contrast staining. The grids were turned over, incubated in the CASblocking solution for $10 \mathrm{~min}$, and then floated on a drop of the second (primary) antibody for $2 \mathrm{~h}$. A different size $(20 \mathrm{~nm})$ of protein A-gold (Sigma Chemical Co.) was used for the second antibody. Upon the completion of the second immunogold reaction, the grids were contrasted with uranyl acetate and lead citrate. The specificity of the reactions obtained was tested using the following controls: (1) replacing the primary antiserum with PBS or (2) doing so with antiserum absorbed with excess complimentary anti- 
gens or with other antigens (if available) to test for cross-reactivity.

\section{RESULTS}

The findings in the ultrastructural study support the earlier view (Al-Mahrouki and Youson, 1998) that there are four primary islet cell types $(\mathrm{A}, \mathrm{B}, \mathrm{D}$, and $\mathrm{F})$ among the four species examined (O. bicirrhosum, $P$. buchholzi, N. chitala, and G. petersii).

The above conclusion was based on the distribution pattern of cells previously described in the immunohistochemical results, on what appeared to be cell-specific granules, and on the immunocytochemical results of this study. In addition, the fine structural observations revealed scattered cells among the exocrine acini which were mainly B- and D-cells.

The endocrine cells could easily be distinguished from the exocrine cells due to the large secretory granules of the latter (Fig. 1). Furthermore, the endocrine cells were in close association with blood vessels and nerve terminals (Figs. 1-3). The islet cells had numerous common features, including a large oval nucleus and large vacuoles (presumably containing only lipid); the latter were particularly pronounced in B-cells (Fig. 3). Well-developed cisternae of rough endoplasmic reticulum and a Golgi apparatus were also observed (Fig. 3). However, notable differences were observed in the morphology of the secretory granules and mitochondria among the cells (Figs. 3-7) and in their immunocytochemistry (Figs. 8 and 9).

In three of the species examined, the B-cells contained granules 93-337 $\mathrm{nm}$ in diameter (measurement made along the longest axis of the granule) each with a loose-fitting membrane surrounding a hexagonal or spherical-shaped matrix (Figs. 2, 3, and 5). However, in O. bicirrhosum, the diameter of B-cell granules had a range of 154-338 $\mathrm{nm}$ and the shape of the granule matrix varied greatly among round, oval, rectangular, triangular, rod, and stacked rods (Fig. 4). The immunocytochemical techniques confirmed the fine structural results, in which B-cell granule cores immunoreacted with anti-mINS serum in all four species, and is indicated by the labeling of protein A-gold particles (compare Figs. 9a and 9b). The immunoreactivity was comparatively weaker in B-cell granules of O. bicirrhosum.

The islet organs of the osteoglossomorphs seemed to have two types of D-cells scattered throughout the islets (Figs. 2, 6, 8a, and 8b). D1-cells had similar

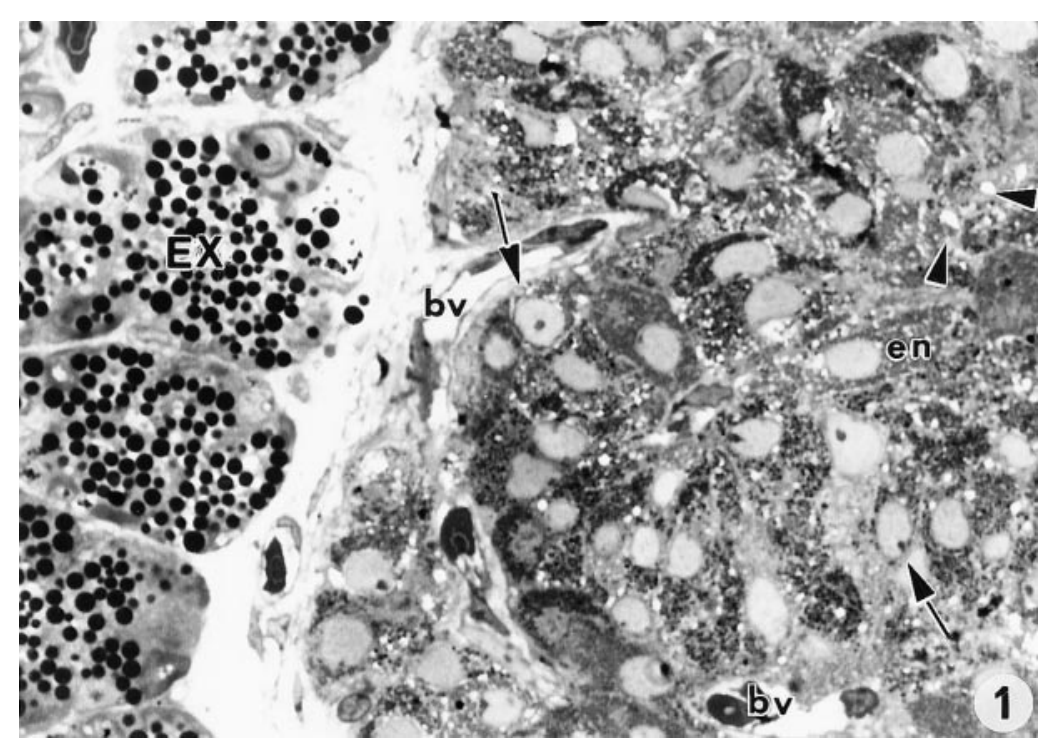

FIG. 1. Light micrograph of a $0.5-\mu \mathrm{m}$ section of a portion of an islet in the pancreas of O. bicirrhosum stained with toluidine blue. The relationship between the exocrine (EX) and the endocrine tissue (en) is illustrated. Note the large oval nucleus (arrows), large lipid inclusions (arrowheads), and blood vessels (bv). $\times 1000$. 


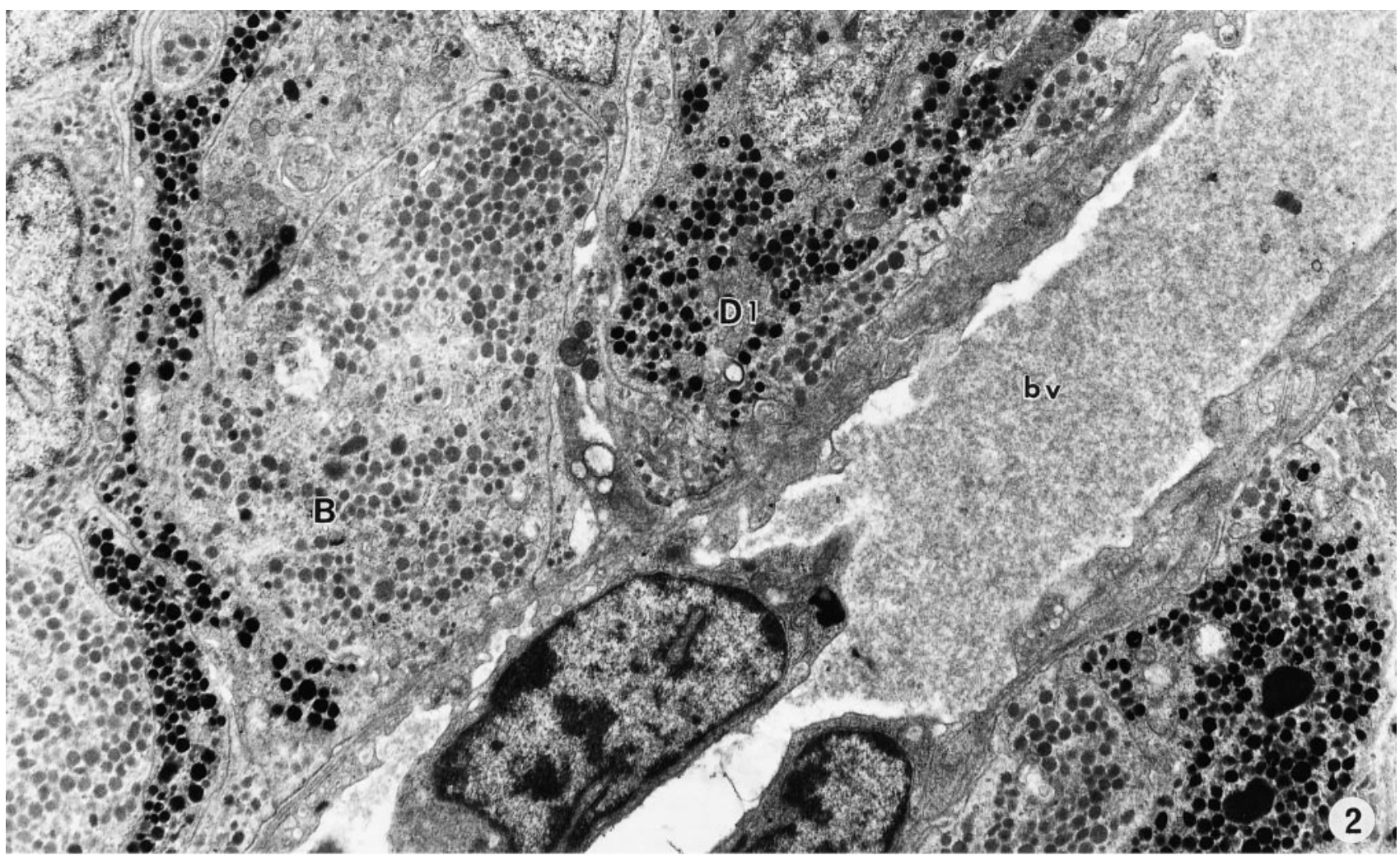

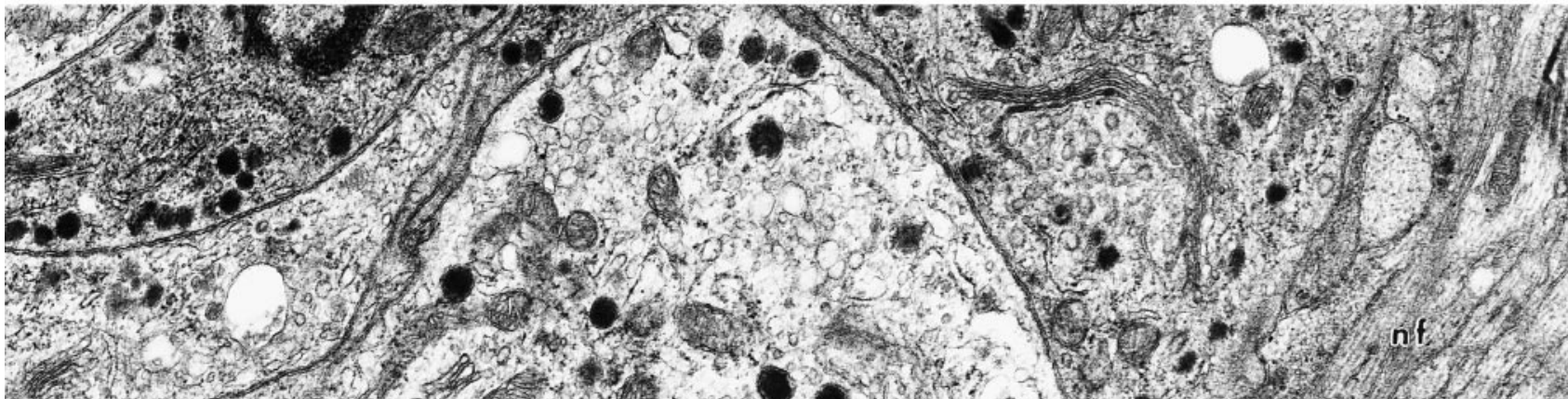

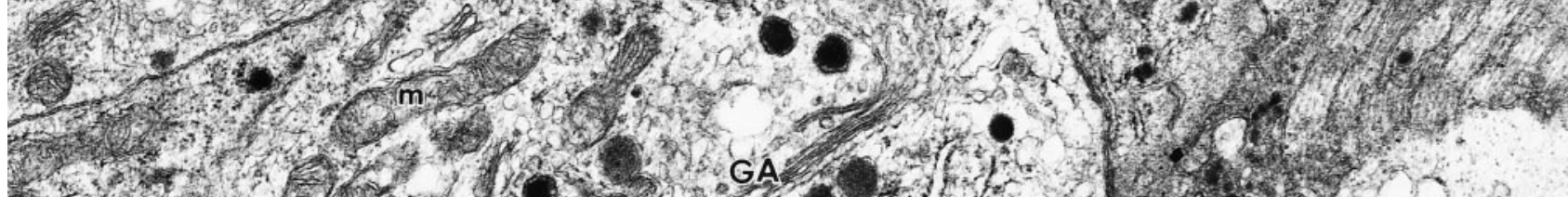

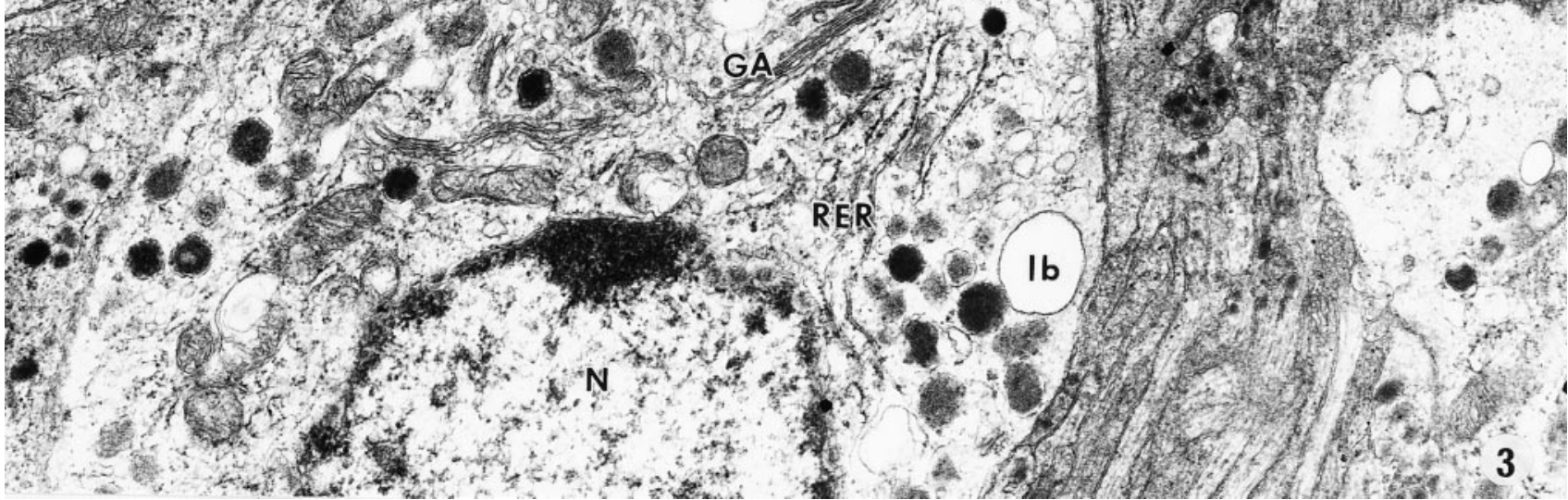

FIG. 2. Low-magnification electron micrograph of a portion of an islet in N. chitala, showing B-cells (B) and D1-cells (D1); bv, blood vessel. $\times 10,000$

FIG. 3. Portion of a B-cell and several unknown cell types in G. petersii. In the B-cell are a Golgi apparatus (GA), mitochondria (m), nucleus (N), a lipid body (lb), and cisternae of rough endoplasmic reticulum (RER). Note the nerve fibers (nf) among the cells. $\times 20,000$. 


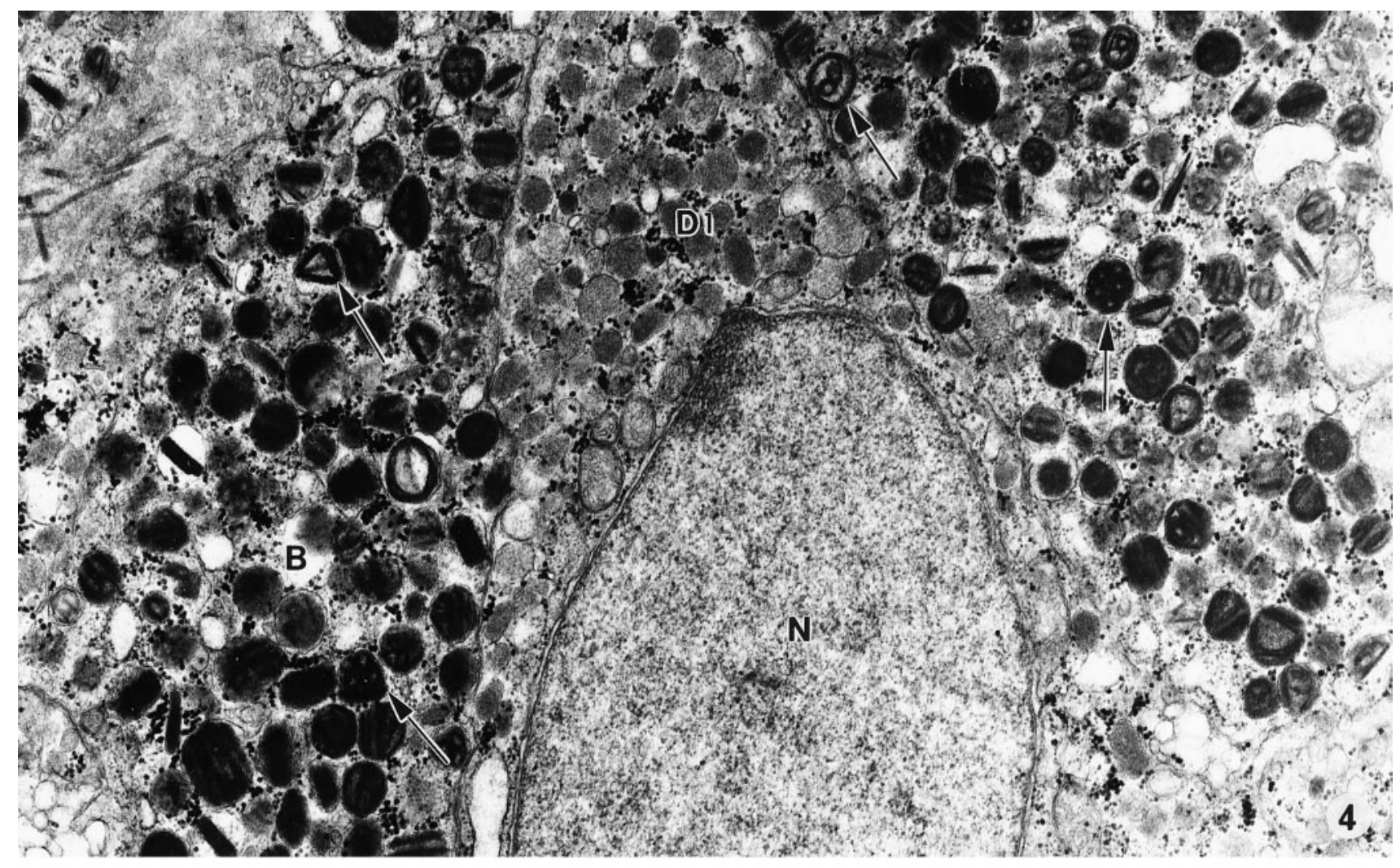

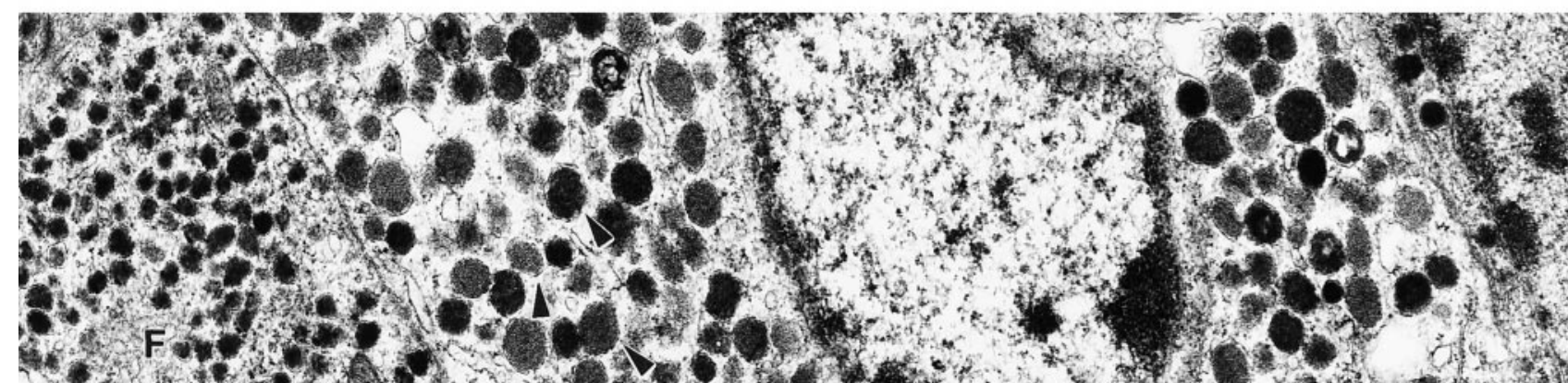

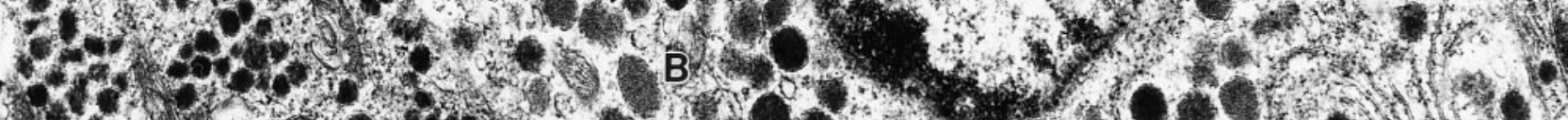

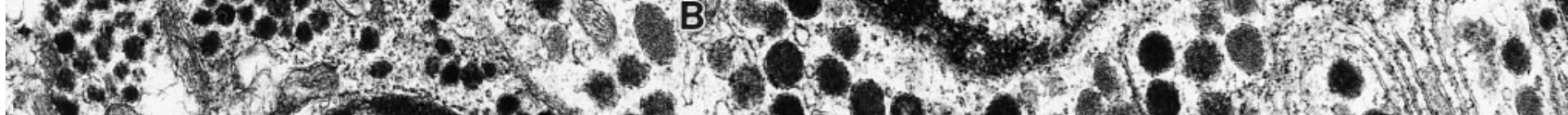

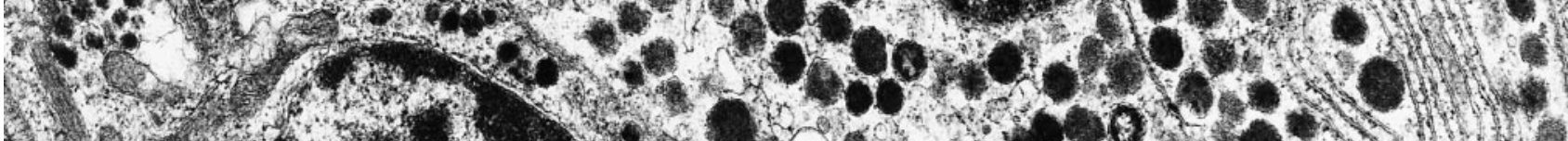

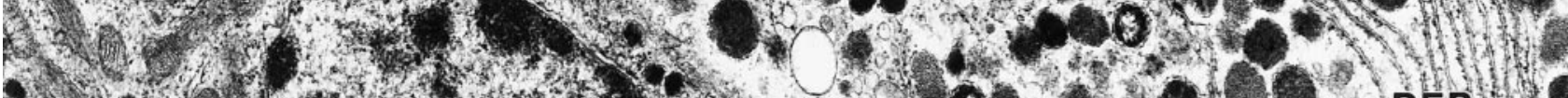
F.m.

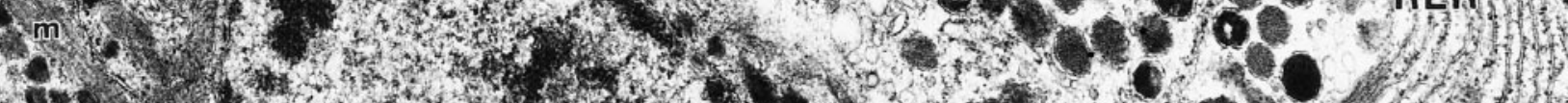

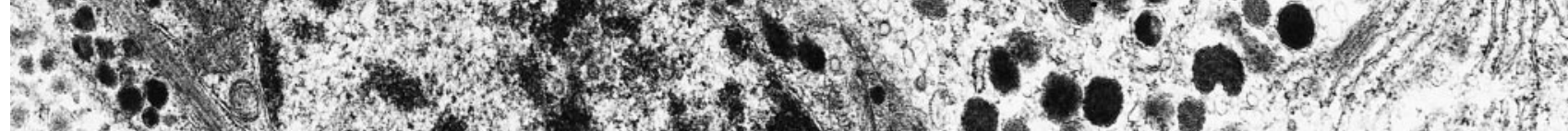
3.

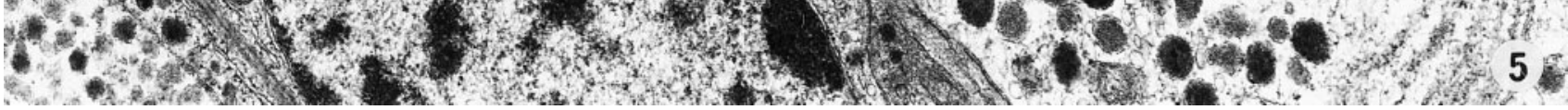

FIG. 4. B-cells (B) and a D1-cell (D1) in O. bicirrhosum. Note the polymorphism of granule cores in B-cells (arrows). The D1 granules have a hranule core with moderate electron density. Nucleus $(N) \times 25,000$.

FIG. 5. F-cell (F) and B-cell (B) in G. petersii. Compare the homogeneous, more spherical, granule cores in the B-cells (arrowheads) with those in Fig. 4. The B-cell is shown with rough endoplasmic reticulum (RER). Note the unusual-shaped mitochondria (m) and the smaller granules in the adjacent F-cell (F). $\times 20,000$. 


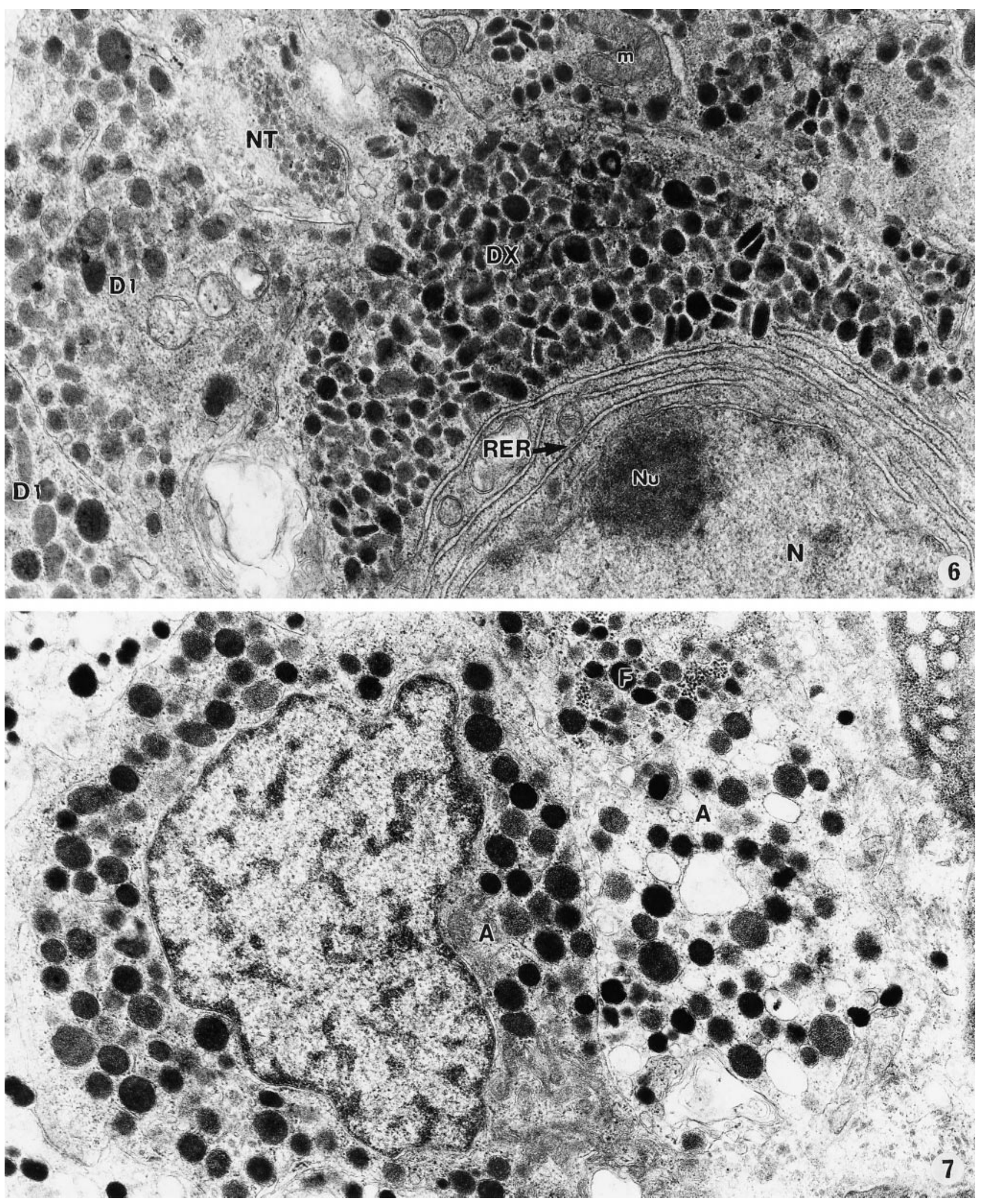

FIG. 6. Different D-cells in P. buchholzi. Note D1-cell type (D1) with round larger granule cores, compared to the DX-cell type (DX) with many rod-like granule cores. Also shown are mitochondria $(\mathrm{m})$, nerve terminals $(\mathrm{NT})$, rough endoplasmic reticulum (RER), nucleus (N), and nucleolus $(\mathrm{Nu}) . \times 25,000$.

FIG. 7. Portions of A-cells (A) and F-cells (F) in O. bicirrhosum. Note the large round and oval granule cores with tight fitting, limiting membrane in the A-cells. Granule cores of F-cell are much smaller. $\times 25,000$. 


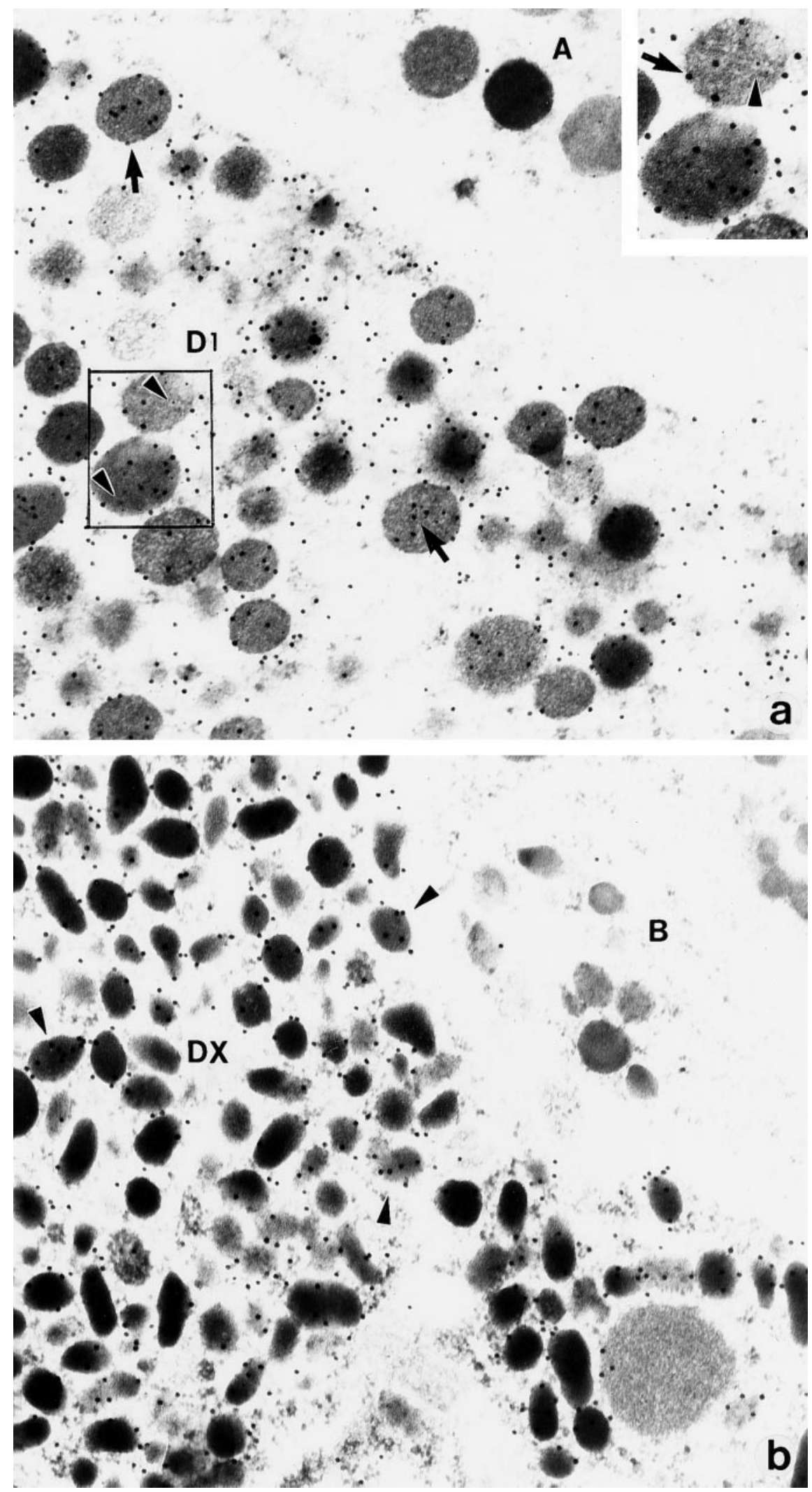

FIG. 8. (a) Double labeling of D1-cell granules in O. bicirrhosum. The 10-nm particles (arrowheads) label the immunoreactivity to anti-SST-14 and the 20-nm particles (arrows) label the immunoreactivity to anti-SST-25. Note the unlabeled granule cores of an adjacent A-cell (A). $\times 48,000$. Inset: higher magnification of the granules indicated in the box. $\times 66,000$. (b) The labeling of DX-cell granules in N. chitala with 20-nm protein A-gold particles (arrowheads) after incubation in anti-SST-34 preabsorbed with SST-14 antigen. The adjacent B-cell (B) granules did not react with the anti-serum. $\times 48,000$. 


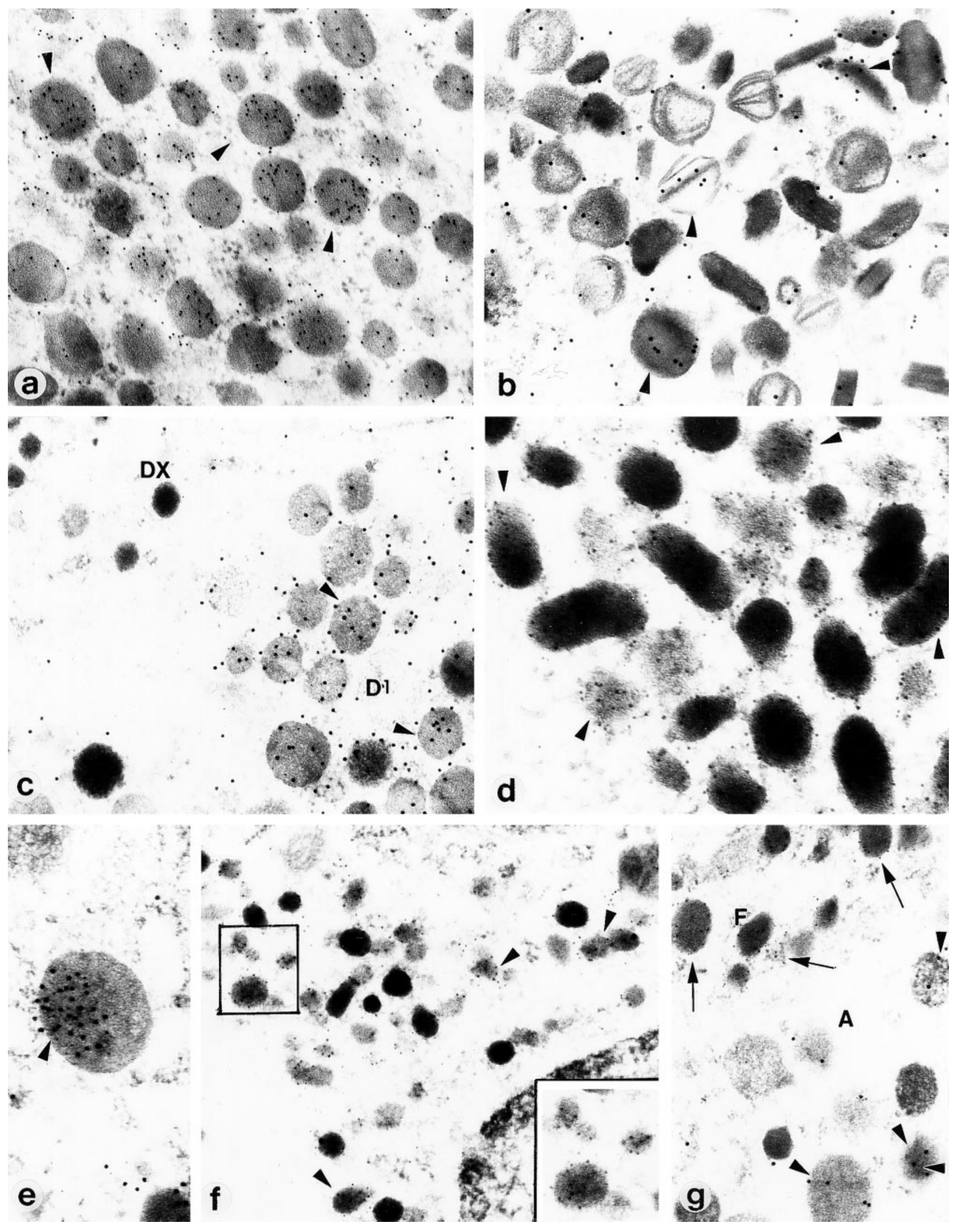


spherical granules of mixed electron density in three species, but the granules were less electron dense in $O$. bicirrhosum (Figs. 4 and 8a). Generally, for all the species the granule diameter ranged from 72 to 320 $\mathrm{nm}$. In contrast, granules in other D-cells, hereafter referred to as DX-cells (Figs. 6 and 8b), were highly electron dense and elongated or tear-drop shaped with a tight limiting membrane and tended to have a more limited diameter range of $69-240 \mathrm{~nm}$ in all examined species. The anti-SST immunoreactivity confirmed the presence of two D-cell types. D1-cell granule matrices immunoreacted with anti-SST-25 and anti-SST-14 (Fig. 9c); this feature was also revealed by the doublelabeling technique (Fig. 8a). DX-cells had different shaped granule cores compared to D1-cells and immunoreacted with anti-SST-34 (Fig. 9d). Furthermore, the absorption of anti-SST-34 with SST-14 antigen prior to application did not abolish the labeling of DX-cell granules (Fig. 8b).

A-cells were located at the periphery of the islets in all four species; some A-cells were scattered toward the middle of the islets in P. buchholzi and in N. chitala. The A-cell granules had a moderate electron density and the diameter ranged between 93 and $385 \mathrm{~nm}$ (Fig. 7),

FIG. 9. (a) Protein A-gold-labeled granules of B-cell (arrowheads) in G. petersii following anti-mINS incubation. Compare the granule cores with those in Fig. 5. $\times 63,000$. (b) Following incubation with anti-mINS serum, gold particles are present over the polymorphic cores of granules (arrowheads) of a B-cell in O. bicirrhosum, indicating the presence of insulin (compare with Fig. 4). Note the smaller numbers of particles over the granules compared to (a). $\times 50,000$. (c) D1-cell type in O. bicirrhosum labeled with protein A-gold particles, following an incubation with SST-25 antiserum (compare with Fig. 4). Note the unlabeled granule cores from a DX-cell. $\times 50,000$. (d) Following incubation with SST-34 antiserum, granules of DX-cells in $N$. chitala label with gold particles, indicating the presence of SST over high, electron-dense granules (arrowheads) with some rodshaped profiles (compare with Fig. 7). ×90,000. (e) Following double incubation, A-cell granules in O. bicirrhosum label with anti-GLU (20-nm particles, arrowhead) but not with anti-PYY (10-nm particles). Compare with Fig. 6. $\times 63,000$. (f) Following double incubation, granules in an F-cell from G. petersii label with anti-PYY (10-nm particles, arrowheads) but not with anti-GLU (20-nm particles). Compare with Fig. 6. $\times 63,000$. Inset: higher magnification of the granules indicated in the box. $\times 90,000$. (g) Adjacent A-cell (A) and F-cell (F) in O. bicirrhosum. Following double incubation, the 20-nm particles (A-cell granules, arrowheads) label the immunoreactivity to anti-GLU and the 10-nm particles (F-cell granules, arrows) label the immunoreactivity to anti-PYY. $\times 50,000$. with a tight-fitting, limiting membrane and oval or circular matrix profiles. Immunoreactivity to anti-GLU serum confirmed the identity of the A-cells (Fig. 9e).

F-cells were found at the very periphery of the islets and possessed much smaller granules (48-200 nm in diameter), and the electron density of the granule cores was less than that of the A-cells (Figs. 5 and 7). The features of the F-cell were similar in the different species examined. F-cell granule cores immunoreacted with anti-PYY serum (Fig. 9f) but not with anti-GLU serum. The double-labeling technique indicated a noncoexistence between the glucagon family peptides and the pancreatic family peptides in all of these species (Fig. 9g). These immunocytochemical results with Aand F-cells were further verified by absorbing the antiserum with excess complimentary antigens or with other antigens to test for cross-reactivity.

\section{DISCUSSION}

The present data indicate the presence of four major cell types, each specifically localizing only one of the following peptides: insulin (B-cell), somatostatin (Dcell), glucagon (A-cell), and a peptide (PYY) of the pancreatic polypeptide family (F-cell). Several studies of the islet organs of teleost fish using immunohistochemical (Langer et al., 1979; Stefan and Falkmer, 1980; Rombout and Taverne-Thiele, 1982; Abad et al., 1986; Wang et al., 1986) and immunocytochemical (Carrillo et al., 1986; Abad et al., 1988; Beccaria et al., 1990; Agulleiro et al., 1993) techniques have revealed the existence of four general endocrine cell types. The present data support our routine light microscopic and immunohistochemical study, which recognized putative A-, B-, D-, and F-cells in osteoglossomorphs (Al-Mahrouki and Youson, 1998).

In earlier reviews it was emphasized that the Bgranules of fish islets are round and do not have the substructure often found in granules of higher vertebrate B-cells (Brinn, 1973). This opinion has been confirmed through subsequent observations of several teleost species (Brinn, 1975; Klein and Lange, 1977; Lozano and Agulleiro, 1986; Carrillo et al., 1986; Agulleiro et al., 1993), although some rod-like crystalloid content was found in a few granules (Klein and Lange, 1977; Carrillo et al., 1986; Agulleiro et al., 1993). In at 
least the sea bass (Dicentrarchus labrax), the crystalloid content was immunoreactive with anti-insulin (Agulleiro et al., 1993). Fibrillar granules were typical of B-cells in Scorpaena scropha (Boquist and Patent, 1971). In Carassius carassius longsdorfi, most B-cell granules contain the needle-like or bar-shaped crystalloids (Kobayashi and Takahashi, 1970). Brinn (1973) concluded that variation in the appearance of B-cell granules in fishes could reflect differences in the molecular configuration of their insulins. For instance, differences in zinc content of insulin molecules has long been suspected to influence polymorphism of B-cell granules in fish (Nakamura and Yokote, 1971) and Wagner et al. (1981) stressed the high incorporation of this metal in B-cells of a teleost. Baker et al. (1988) reported that the insulin molecule forms a hexamere upon binding the zinc, and that gives the insulin granule core its characteristic hexagonal or round shape, while the zinc-free insulin forms dimers or monomers. There was similarity in shape of the insulin granule cores in three of the osteoglossomorph species studied (P. buccholzi, N. chitala, and G. petersii). Since their granules were hexagonal or round shape, it suggests that their insulins have similar conformation and that they are Zn-binding. However, in O. bicirrhosum the conformation of the insulin molecule may be different from that of the other three species, resulting in a greater diversity of shapes in the granule matrices. In addition, it was noted that the immunoreactivity of B granules to mammalian insulin antiserum in O. bicirrhosum was weaker than that of the other species.

There may be some taxonomic significance in the differences in insulin granules among osteoglossomorphs, for genus Osteoglossum is clearly distant from at least two of the genera studied (Notopterus and Gnathonemus) and its relationship to the other member of suborder Osteoglossoidei (Pantodon) is unclear (Li and Wilson, 1996). Nelson (1994) places the genera Osteoglossum and Pantodon in different families. The difference in structure of B-granules in the osteoglossomorphs studied may be explained following an analysis of the primary and secondary structures of their insulin molecules.

Several studies identified different forms of somatostatin in teleosts (Hobart et al., 1980; Plisetskaya et al., 1986; Conlon et al., 1987, 1988), including SST-14 I and II, SST-25, and SST-28, involving two distinct genes
(Conlon et al., 1997; Kittilson et al., 1999). Gene I encodes for a preprosomatostatin that will be processed to give SST-28 and/or SST-14 I, whereas gene II encodes for a preprosomatostatin that will be processed to give either a 28-residue peptide or a 25residue peptide with SST-14 II $\left(\mathrm{Tyr}^{7}, \mathrm{Gly}^{10}\right)$. Many teleosts (anglerfish, coho salmon, rainbow trout, sea bass, and turbot) have two distinct D-cell types immunoreactive to either SST-14 or SST-25 antisera (McDonald et al., 1987; Nozaki et al., 1988; Lozano et al., 1991a; Abad et al., 1992; Garcia-Hernandez and Agulleiro, 1992; Reinecke et al., 1997). Furthermore, the separate subpopulations of islet cells of these teleosts have different anatomical relationships with other cell types in the islet, mainly SST-14 containing D2-cells near central B-cells and SST-25 containing D1-cells at the periphery (Agulleiro et al., 1993; Reinecke et al., 1997). In contrast, the more ancient, nonteleost actinopterygian, the gar, showed only a single type of D-cell (Groff and Youson, 1997, 1998).

Another form of somatostatin, SST-34, was isolated from lamprey (Andrews et al., 1988). The use of antisera to SST-34 in osteoglossomorphs yielded a D-cell, which was not immunoreactive to anti-salmon SST-25 or to anti-SST-14. This cell, which we termed a DX-cell, also had granules of a different shape compared to those of the D1-cell, which were immunoreactive with anti-SST-25 and anti-SST-14. This result implies that the SST-34 antiserum has been directed against a portion of lamprey SST-34 that cannot be recognized in the SST(s) in the D1-cells and that DX-cells have an SST in a different conformation or perhaps a different SST than that present in D1-cells. Thus, the osteoglossomorphs share the common feature of other teleosts of having two types of D-cells in the pancreatic islets. The immunoreactivity to both anti-SST-14 and anti-SST-25 in D1-cells of the osteoglossomorph islet organ is consistent with that reported for D1-cells in the developing and mature islet organ of sea bass (Lozano et al., 1991a; Garcia-Hernandez and Agulleiro, 1992). Moreover, similar coexistence was reported in the stomach of Sparus aurata (Elbal et al., 1991). However, D1-cells in osteoglossomorphs are distributed throughout the islet tissue (Al-Mahrouki and Youson, 1998) in comparison to the peripheral distribution in teleosts (e.g., Reinecke et al., 1997). In contrast, the DX-cells in osteoglossomorphs are spread 
throughout the islet, like D2-cells of other teleosts. The reason for two subpopulations of D-cells in teleosts is not known, but each type may have a different paracrine action on the other endocrine cells (Abad et al., 1992; Reinecke et al., 1997) and/or there could be independent functions for the different SSTs released from cells of the islet organ of teleosts (Nozaki et al., 1988; Plisetskaya, 1990).

The pancreatic polypeptide-like (PP) peptides, pancreatic polypeptide (PP), peptide YY (PYY), and neuropeptide $\mathrm{Y}(\mathrm{NPY})$, have a similar molecular structure and seem to be derived from a single ancestral gene (Tatemoto, 1982a,b; Tatemoto et al., 1982; Conlon, 1995; Larhammar, 1996). All of these 36-amino acid polypeptides show cross-reactivity (Laburthe et al., 1986; Inui et al., 1988). Furthermore, in many vertebrate species, including fish, these peptides are often colocalized with peptides of the glucagon family (Lozano et al., 1991b; Agulleiro et al., 1993). Coexistence between glucagon and neuropeptide $\mathrm{Y}$ was also reported in the gar islet organ (Groff and Youson, 1998).

Herrera et al. (1991) reported that during early development of murine pancreas, most glucagonimmunoreacting cells contain PP immunoreactivity, whereas in the later stages, the frequency of only one of the two hormones in distinct cells increases. However, in turbot (Scophthalmus maximus) both peptides appeared in distinct islet cells throughout the various developmental stages (Berwert et al., 1995). In osteoglossomorphs two distinct cells immunoreacted with either anti-GLU (A-cell) or anti-PYY (F-cell). The size and shape of the cytoplasmic granules in the F-cells of the osteoglossomorphs were similar to those of the NPY-positive cells in the embryonic pancreas (54-mm stage) of the dogfish (Chiba et al., 1995). The coexistence of peptides of the glucagon and polypeptide families in the GEP system of bony fish and other vertebrates is still a curiosity. Present results show species-specific differences among teleosts that may be related to the existence or absence of an ancestral cell type or a molecular processing mechanism pertaining to glucagon and pancreatic polypeptides (Putti et al., 1991).

In summary, the present observations indicate species differences among the Osteoglossomorpha in the nature of B-cell granules, but all species share the feature of two subpopulations of D-cells, similar to more derived teleosts; the latter is thus a consistent teleost character. However, distribution and immunoreactivity of the two D-cell types is different in osteoglossomorphs and other teleosts. The number of islet cell types has some phylogenetic relevance among the vertebrates (Falkmer, 1995). In this context, the existence of four cell types (A, B, D, and F) in the islet organ of osteoglossomorphs suggests a more derived position for this group compared to Semionotiformes (e.g., gar) among the Actinopterygii (Groff and Youson, 1998). In conclusion, the findings of the study are of some taxonomic significance to osteoglossomorph speciation and to the Osteoglossomorpha among the Teleostei and other Actinopterygii.

\section{ACKNOWLEDGMENTS}

The authors thank Raymond Or for his technical help. This study was supported by a grant from the National Sciences and Engineering Research Council of Canada to J.H.Y.

\section{REFERENCES}

Abad, M. E., Agulleiro, B., and Rombout, J. H. W. M. (1986). An immunocytochemical and ultrastructural study of the endocrine pancreas of Sparus auratus L. (Teleostei). Gen. Comp. Endocrinol. 64, $1-12$.

Abad, M. E., Taverne-Thiele, J. J., and Rombout, J. H. W. M. (1988). Immunocytochemical characterization of coexistence of pancreatic polypeptide and glucagon-like immunoreactivity in the pancreatic endocrine cells of Sparus auratus L. (Teleostei). Gen. Comp. Endocrinol. 70,9-19.

Abad, M. E., Garcia Ayala, A., Lozano, M. T., and Agulleiro, B. (1992). Somatostatin 14- and somatostatin-25-like peptides in pancreatic endocrine cells of Sparus aurata (Teleost): A light and electron microscopic immunocytochemical study. Gen. Comp. Endocrinol. 86, 445-452.

Agulleiro, B., Lozano, M. T., Abad, M. E., and Garcia Hernandez, M. P. (1993). Electron-microscopic immunocytochemical study of the endocrine pancreas of sea bass Dicentrarchus labrax. Cell Tissue Res. 274, 303-314.

Al-Mahrouki, A. A., and Youson, J. H. (1998). Immunohistochemical studies of the endocrine cells within the gastro-entero-pancreatic system of Osteoglossomorpha, an ancient teleostean group. Gen. Comp. Endocrinol. 110, 125-139. 
Andrews, P. C., Pollock, H. G., Elliott, W. M., Youson, J. H., and Plisetskaya, E. M. (1988). Isolation and characterization of a variant somatostatin-14 and two related somatostatins of 34 and 37 residues from lamprey (Petromyzon marinus). J. Biol. Chem. 263, 15809-15814.

Baker, E. N., Blundell, T. L., Cutfield, J. F., Cutfield, S. M., Dodson, E. J., Dodson, G. G., Hodgkin, D. M. C., Hubbard, R. E., Isaacs, N. W., Reynolds, C. D., Sakabe, K., Sakabe, N., and Vijayan, N. M. (1988). The structure of $2 \mathrm{Zn}$ pig insulin crystals at $1.5 \AA$ resolution. Phil. Trans. R. Soc. Lond. B 319, 369-456.

Beccaria, C., Diaz, J.-P., Gabrion, J., and Connes, R. (1990). Maturation of the endocrine pancreas in the sea bass, Dicentrarchus labrax L. (Teleostei): An immunocytochemical and ultrastructural study. 1. Glucagon-producing cells. Gen. Comp. Endocrinol. 78, 80-92.

Berwert, L., Segner, H., and Reinecke, M. (1995). Ontogeny of IGF-I and the classical islet hormones in the turbot, Scophthalmus maximus. Peptides 16, 113-122.

Boquist, L., and Patent, G. (1971). The pancreatic islets of the teleost Scorpaena scropha: An ultrastructural study with particular regard to fibrillar granules. Z. Zellforsch. 115, 416-425.

Brinn, J. E., Jr. (1973). The pancreatic islets of bony fishes. Am. Zool. 13, 653-665.

Brinn, J. E. (1975). Pancreatic islet cytology of Ictaluridae (Teleostei). Cell Tissue Res. 162, 357-365.

Carrillo, M., Zanuy, S., Duve, H., and Thorpe, A. (1986). Identification of hormone-producing cells of the endocrine pancreas of the sea bass, Dicentrachus labrax, by ultrastructural immunocytochemistry. Gen. Comp. Endocrinol. 61, 287-301.

Chiba, A., Honma, Y., and Oka, S. (1995). Ontogenetic development of neuropeptide-Y-like immunoreactive cells in the gastroenteropancreatic endocrine system of the dogfish. Cell Tissue Res. 282, 33-40.

Conlon, J. M., Davis, M. S., Falkmer, S., and Thim, L. (1987). Structural characterization of peptides derived from prosomatostatins I and II isolated from the pancreatic islets of two species of teleostean fish: The daddy sculpin and the flounder. Eur. J. Biochem. 168, 647-652.

Conlon, J. M., Deacon, C. F., Hazon, N., Henderson, I. W., and Thim, L. (1988). Somatostatin-related and glucagon-related peptides with unusual structural features from the European eel Anguilla anguilla. Gen. Comp. Endocrinol. 72, 181-189.

Conlon, J. M. (1995). Peptide tyrosine-tyrosine (PYY)-An evolutionary perspective. Am. Zool. 35, 466-473.

Conlon, J. M., Tostivint, H., and Vaudry, H. (1997). Somatostatin- and urotensin II-related peptides: Molecular diversity and evolutionary perspectives. Regul. Pept. 69, 95-103.

Elbal, M. T., Garcia, A. A., and Agulleiro, B. (1991). Light and electron microscopic immunocytochemical demonstration of coexistence of somatostatin 14- and somatostatin 25-like peptides in endocrine cells of the stomach of Sparus auratus L. Gen. Comp. Endocrinol. 84, $36-43$.

Epple, A., and Brinn, J. E. (1975). Islet histophysiology: Evolutionary correlations. Gen. Comp. Endocrinol. 27, 320-349.

Falkmer, S. (1995). Origin of the parenchymal cells of the endocrine pancreas: Some phylogenetic and ontogenetic aspects. In "Endocrine Tumors of the Pancreas," Vol. 23, "Frontiers in Gastrointesti- nal Research" (M. Mignon and R. T. Jansen, Eds.), pp. 2-29. Karger, Basel.

Garcia-Hernandez, M. P., and Agulleiro, B. (1992). Ontogeny of the endocrine pancreas in sea bass (Dicentrarchus labrax). Cell Tissue Res. 270, 339-352.

Gardiner, B. G., Maisey, J. G., and Littlewood, D. T. J. (1996). Interrelationships of basal neopterygians. In "Interrelationships of Fishes" (M. L. J. Stiassny, L. R. Parenti, and G. D. Johnson, Eds.), pp. 117-146. Academic Press, San Diego.

Gomez-Visus, I., Abad, M. P., Hernandez, G., and Agulleiro, B. (1996). Occurrence of somatostatin and insulin immunoreactivities in the stomach of sea bass (Dicentrarchus labrax L.): Light and electron microscopic studies. Gen. Comp. Endocrinol. 102, 16-27.

Groff, K., and Youson, J. H. (1997). An immunohistochemical study of the endocrine cells within the pancreas, intestine, and stomach of the gar (Lepisosteus osseus L.). Gen. Comp. Endocrinol. 106, 1-16.

Groff, K. E., and Youson, J. H. (1998). Fine structure and immunocytochemistry of cells within the endocrine pancreas of the gar (Lepisosteus osseus). Can. J. Zool. 76, 6-18.

Herrera, P-L., Huarte, J., Sanvito, F., Meda, P., Orci, L., and Vassalli, J-D. (1991). Embryogenesis of the murine endocrine pancreas: Early expression of pancreatic polypeptide gene. Development 133, 1257-1265.

Hobart, P., Crawford, R., Shen, L. P., Pictet, R., and Rutter, W. J. (1980). Cloning and sequence of cDNAs encoding two distinct somatostatin precursors found in the endocrine pancreas of anglerfish. Nature 288, 137-141.

Inui, A., Oya, M., Inoue, T., Sakatina, N., Morioka, H., Shii, K., Yokomo, K., Mizuno, N., and Baba, S. (1988). Peptide YY receptors in the brain. Biochem. Biophys. Res. Commun. 150, 25-32.

Kittilson, J. D., Moore, C. A., and Sheridan, M. A. (1999). Polygenic expression of somatostatin in rainbow trout, Oncorhynchus mykiss: Evidence of a preprosomatostatin encoding somatostatin-14. Gen. Comp. Endocrinol. 114, 88-96.

Klein, C., and Lange, R. H. (1977). Principal cell types in the pancreatic islet of a teleost fish, Xiphophorus helleri H. Cell Tissue Res. 176, 529-551.

Kobayashi, K., and Takahashi, Y. (1970). Light and electron microscopic observations on the islets of Langerhans in Carassius carassius longsdorfii. Arch. Histol. Jpn. 31, 433-454.

Laburthe, M., Chenut, B., Rouyer-Fessard, C., Tatemoto, K., Couvineau, A., Servin, A., and Amiranoff, B. (1986). Interaction of peptide $Y Y$ with rat intestinal epithelial plasma membranes: Binding of the radioiodinated peptide. Endocrinology 118, 19101917.

Langer, M., Van Noorden, S., Polak, J. M., and Pearse, AGE. (1979). Peptide hormone-like immunoreactivity in the gastrointestinal tract and endocrine pancreas of eleven teleost species. Cell Tissue Res. 199, 493-508.

Larhammar, D. (1996). Evolution of neuropeptide Y, peptide YY and pancreatic polypeptide. Regul. Pept. 62, 1-11.

Li, G. Q., and Wilson, M. V. H. (1996). Phylogeny of Osteoglossomorpha. In "Interrelationships of Fishes" (M. L. Stiassny, L. R. Parenti, and G. D. Johnson Eds.), pp. 163-174. Academic Press, London. 
Lozano, M. T., and Agulleiro, B. (1986). Immunocytochemical and ultrastructural study of the endocrine pancreas of Mugil auratus and Mugil saliens L. (Teleostei). J. Submicrosc. Cytol. 18, 85-98.

Lozano, M. T., Garcia Ayala, A., Abad, M. E., and Agulleiro, B. (1991a). Pancreatic endocrine cells in sea bass (Dicentrarchus labrax L.). II. Immunocytochemical study of insulin and somatostatin peptides. Gen. Comp. Endocrinol. 81, 198-206.

Lozano, M. T., Garcia Ayala, A., Abad, M. E., and Agulleiro, B. (1991b). Pancreatic endocrine cells in sea bass (Dicentrarchus labrax L.). I. Immunocytochemical characterization of glucagon- and PP-related peptides. Gen. Comp. Endocrinol. 81, 187-197.

McDonald, J. K., Greiner, F., Bauer, G. E., Elde, R. P., and Noe, B. D. (1987). Separate cell types that express two different forms of somatostatin in anglerfish islets can be immunohistochemically differentiated. J. Histochem. Cytochem. 35, 155-162.

McCormick, N. A. (1925). The distribution and structure of the islands of Langerhans in certain fresh water and marine fishes. Trans. R. Can. Inst. 15, 57-81.

Millonig, G. (1961). Advantages of a phosphate buffer for $\mathrm{OsO}_{4}$ solutions in fixation. J. Appl. Phys. 32, 1637. [Abstract]

Nakamura, M., and Yokote, M. (1971). Ultrastructural studies on the islets of Langerhans of the carp. Z. Anat. Entwickl. Gesch. 134, 61-72.

Nelson, J. S. (1994). "Fishes of the World," 3rd ed. Wiley, New York.

Nozaki, M., Miyata, K., Oota, Y., Gorbman, A., and Plisetskaya, E. M. (1988). Different cellular distributions of two somatostatins in brain and pancreas of salmonids, and their associations with insulin- and glucagon-secreting cells. Gen. Comp. Endocrinol. 69, 267-280.

Patterson, C., and Rosen, D. E. (1977). Review of ichthyodectiform and other Mesozoic teleost fishes and the theory and practice of classifying fossils. Bull. Am. Mus. Nat. Hist. 158, 81-172.

Plisetskaya, E. M. (1990). Recent studies of fish pancreatic hormones: Selected topics. Zool. Sci. 7, 335-353.

Plisetskaya, E. M., Pollock, H. G., Rouse, J. B., Hamilton, J. W.,
Kimmel, J. R., Andrews, P. C., and Gorbman, A. (1986). Characterization of coho salmon (Oncorhynchus kisutch) islet somatostatins. Gen. Comp. Endocrinol. 63, 252-263.

Putti, R., Varano, L., Cavagnuolo, A., and Laforgia, V. (1991). The endocrine pancreas of Podarcis s. sicula RAF: An immunocytochemical study at light and electron microscopic levels. Eur. J. Basic Appl. Histochem. 35, 145-159.

Reinecke, M., Muller, C., and Segner, H. (1997). An immunohistochemical analysis of the ontogeny, distribution and coexistence of 12 regulatory peptides and serotonin in endocrine cells and nerve fibers of the digestive tract of the turbot, Scophthalmus maximus (Teleostei). Anat. Embryol. 195, 87-102.

Rombout, J. H. W. M., and Taverne-Thiele, J. J. (1982). An immunocytochemical and electron-microscopical study of endocrine cells in the gut and pancreas of stomachless teleost fish, Barbus conchonius (Cyprinidae). Cell Tissue Res. 227, 577-593.

Stefan, Y., and Falkmer, S. (1980). Identification of four endocrine cell types in the pancreas of Cottus scorpius (Teleostei) by immunofluorescence and electron microscopy. Gen. Comp. Endocrinol. 42, 171-178.

Tatemoto, K. (1982a). Isolation and characterization of peptide YY (PYY), a candidate gut hormone that inhibits pancreatic exocrine secretion. Proc. Natl. Acad. Sci. USA 79, 2514-1518.

Tatemoto, K. (1982b). Neuropeptide Y: The complete sequence of the brain peptide. Proc. Natl. Acad. Sci. USA 79, 5485-5489.

Tatemoto, K., Carlquist, M., and Mutt, V. (1982). Neuropeptide Y: A novel brain peptide with structural similarities to peptide $Y Y$ and pancreatic polypeptide. Nature 285, 417-418.

Wagner, G. F., McKeown, B. A., and Popham, D. J. (1981). The autoradiographic localization of zinc within the pancreatic islets of the rainbow trout, Salmo gairdneri. Histochemistry 72, 113-121.

Wang, Y-Q., Plisetskaya, E. M., Baskin, D. G., and Gorbman, A. (1986). Immunocytochemical study of the pancreatic islets of the Pacific salmon, Oncorhynchus kisutch. Zool. Sci. 3, 123-129. 